\title{
Bisepoxide-activated Hollow Silica Microspheres for Covalent Immobilization of Lipase from Burkholderia cepacia
}

\author{
Flóra Nagy¹, Kinga Szabó1, Péter Bugovics¹, Gábor Hornyánszky1,2* \\ 1 Department of Organic Chemistry and Technology, Faculty of Chemical Technology and Biotechnology \\ Budapest University of Technology and Economics, Műegyetem rkp. 3, H-1111 Budapest, Hungary \\ 2 SynBiocat LLC., Szilasliget u. 3, H-1172 Budapest, Hungary \\ *Corresponding author, e-mail: hornyanszky@mail.bme.com
}

Received: 10 June 2018, Accepted: 30 September 2018, Published online: 28 February 2019

\begin{abstract}
An efficient and easy-to-perform method was developed for covalent immobilization of lipase from Burkholderia cepacia (Lipase PS) on hollow silica microspheres (M540) by bisepoxide activation. For immobilization, various bisepoxides of different length, rigidity and hydrophobicity in their linkers were applied to activate the amino groups on the M540 support. Effect of the individual bisepoxides on the catalytic performance of the immobilized Lipase PS was studied by using lipase-catalyzed kinetic resolution (KR) of racemic 1-phenylethanol (rac-1) with vinyl acetate in batch mode. Catalytic activity, enantiomer selectivity, recyclability and thermal stability of the new immobilized Lipase PS biocatalysts were investigated. The optimal enzyme / support ratio with the support activated by the most efficient bisepoxide, i.e. poly(ethylene glycol) diglycidyl ether (PDE), was 1:5. The most efficient Lipase PS on PDE activated M540 showed an almost five fold higher biocatalytic activity value $\left(r_{\text {batch }}=42.8 \mathrm{U} / \mathrm{g}\right)$ with enhanced selectivity $\left(e e_{(R)-2}=99.1 \%\right)$ to the free form of Lipase PS ( $\left.r_{\text {batch }}=9.0 \mathrm{U} / g ; e e_{(R)-2}=98.9 \%\right)$. The Lipase PS on PDE-M540 was compared to a commercially available immobilized Lipase PS biocatalyst (Lipobond Lipase PS) and also applied in a packed-bed enzyme reactor operated in continuous-flow mode, where the optimal temperature of M540-PDE-PS reached the $70^{\circ} \mathrm{C}$, while the optimum for Lipobond Lipase PS was $50^{\circ} \mathrm{C}$.
\end{abstract}

Keywords

Lipase PS, surface modification, covalent immobilization, kinetic resolution, continuous-flow reactor

\section{Introduction}

Biocatalysis is becoming increasingly important as an efficient and green tool for modern organic synthesis $[1,2]$. The biocatalytic process cannot be realized without enzymes. Enzymes are widely applied, for instance, in the fields of chemistry, biochemistry, medicine, or in the pharmaceutical, food and textile industries [3, 4]. Advantages of enzymes as biocatalysts are their high activity, selectivity, specificity and low toxicity combined with their capability to being used under mild reaction conditions and a limited formation of by-products. Enzymes are biodegradable and usually act under physiological conditions, which make them eco-friendly catalysts $[5,6]$.

In spite of all their advantages of the native enzymes, their use as biocatalyst is only rewarding if it is economically viable. Easy denaturation of their molecular structure at high temperatures, at acidic or basic $\mathrm{pH}$ or in the presence of several organic solvents may strictly limit their recovered applications. Most often, enzymes are mixed with substrate in a dilute solution and may not be recovered economically and are generally wasted.

Immobilization of the enzyme can solve their recovery and may also improve many other features of the enzyme such as stability, activity and selectivity of the enzyme $[1,7-16]$. What is more, they are reusable, what is economically more sustainable, and the separation of immobilized biocatalyst from the reaction mixture is more easy. Various immobilization techniques have been developed, including adsorption, covalent binding, entrapment, encapsulation and cross-linking [17-23]. Selection of materials for immobilization has an effect on the properties of immobilized enzymes [24-26]. Immobilization of the biocatalysts onto solid supports has become a robust and widely accepted industrial technique. A very broad variety of materials can be used as supports for enzyme immobilization [27]. These materials may be divided into organic [28], inorganic [29] and hybrid [30] or composite [31]. 
The support should protect the enzyme structure against harsh reaction conditions and thus help the immobilized enzyme to retain high catalytic activity. Porous silica is one of the most frequently used inorganic support materials for enzyme immobilization. Its high thermal and chemical resistance and good mechanical properties make it a suitable material for many practical applications. Due to its high surface area and porous structure, silica offers good adsorption properties with reduced diffusional limitations and last but not least the possibility of functionalization $[13,32]$.

Thus e.g. covalent bonds can be formed involving heterofunctionalized epoxy supports [33-35]. Epoxy functions can react with different nucleophilic groups (such as amine, thiol or carboxylate) on the protein surface under mild conditions and these advantageous properties led to the idea of using bis-epoxides for enzyme immobilization. Thus, poly(ethylene-glycol)-diglycidyl ether was applied for binding various oxidases onto a biosensor microelectrode [36]. Glycerol diglycidyl ether was used as cross-linking agent for immobilization of lipases and phenylalanine ammonia-lyase (PAL) yielding crosslinked enzyme aggregates (CLEAs) [10]. Later, a method was developed for immobilization of Candida antarctica lipase B (CALB) [37] and $\omega$-transaminase from Chromobacterium violaceum (CVTA) [38] on bisepoxide activated mesoporous aminoalkyl polymer supports. Lipases (EC 3.1.1.3) represent one of the most frequently used class of enzymes due to their ability to catalyze a wide range of reactions in a mild and selective manner, thus they were ideal targets for immobilization studies [39-42]. E.g. lipase from Burkholderia cepacia, formerly known as Pseudomonas cepacia lipase (Lipase PS), is a commercial enzyme in both soluble and immobilized forms widely recognized for its thermal resistance and tolerance to a large number of solvents and short-chain alcohols [43]. The main applications of this lipase are in transesterification reactions $[44,45]$ and in the synthesis of drugs. This enzyme is a widely applied for highly enantiomer selective resolution of racemic primary and secondary alcohols [46-49].

Lipases have a mechanism of catalysis that differentiates them from standard esterases and permits that they act in interfaces of insoluble drops of substrates: the interfacial activation [50,51]. The active center may be closed by a polypeptide chain, which can move giving two different forms of lipases: the open and active form, or the closed and many times inactive one $[52,53]$. The open form of lipases tends to become adsorbed on any hydrophobic surface via the huge hydrophobic pocket formed by the active center and the internal face of the lid $[8,54]$. Because of this conformational mobility influencing the catalytic activity, the final outcome of the biocatalytic properties of immobilized lipases can be influenced by various activating agent during the covalent attachment.

In the present study (Fig. 1), Matspheres 540 (M540) a porous hollow silica microsphere support (size of particles: $10-30 \mu \mathrm{m}$, pore size: $15-30 \mathrm{~nm}$ ) covered with polar and non-polar chemical groups on the surface, was studied as carrier for covalent immobilization of Lipase PS at the first time. M540 was especially developed for enzyme immobilization and other bioapplications. The physical properties (size, pore size) of M540 are different from conventional silicas (e.g. Kieselgel 60) as the carrier has a smaller size with smaller, shorter channels, which can reduce the diffusion limitation for the substrate and product. Surface activation of M540 was performed using a variety of bisepoxide activating agents to maximize stability and activity of the enzyme after immobilization. Enzyme loading capacity of the activated carrier and reusability of the best immobilized biocatalyst were investigated. Furthermore, to promote the practical application of the novel biocatalyst Lipase PS immobilized onto

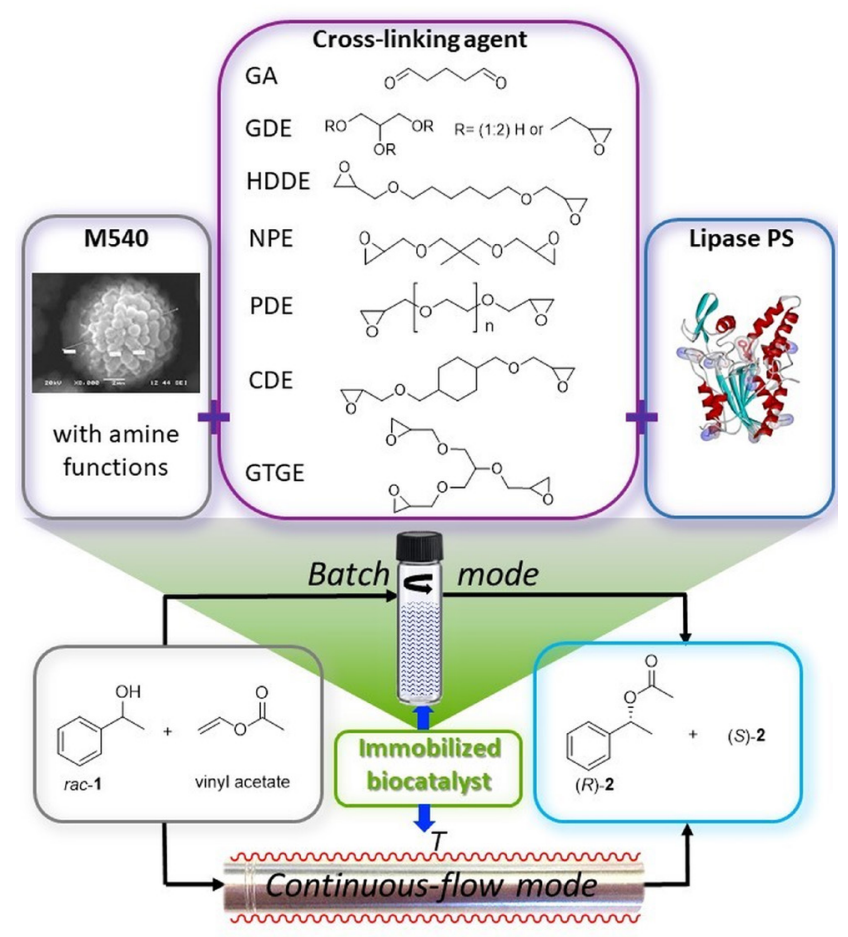

Fig. 1 Immobilization of Lipase PS onto surface functionalized M540 and application of the biocatalyst in kinetic resolution of racemic 1-phenylethanol in batch and continuous-flow mode 
M540 biocatalysts, effect of temperature on a lipase-catalyzed kinetic resolution (KR) was also studied by using an immobilized Lipase PS-filled packed-bed reactor (our best immobilized preparation and the commercially available Lipobond Lipase PS) operated in continuous- flow mode.

\section{Experimental section}

\subsection{Chemicals and enzymes}

Racemic 1-phenylethanol (rac-1), 2-propanol (IPA), GA (glutaraldehyde), PDE (poly(tetra ethylene oxide) diglycidyl ether), NPE (neopentyl glycol diglycidyl ether), GDE (glycerol diglycidyl ether), CDE (cyclohexanedimethanol diglycidyl ether), HDDE (1,6-hexanediol diglycidyl ether), GTGE (glycerol triglycidyl ether), monobasic sodium phosphate, disodium phosphate heptahydrate, vinyl acetate, $n$-hexane, tert-buthyl methyl ether (MTBE), acetone, toluene and ethanol were commercial products of Alfa-Aesar Europe (Karlsruhe, Germany), Sigma-Aldrich (Saint Louis, MO, USA) or Merck (Darmstadt, Germany). M540 was the product of Materium Innovations (Granby, Canada). M540-PDE, M540-NPE, M540-GDE, M540CDE, M540-HDDE and M540-GTGE supports were the products of SynBiocat LLC. (Budapest, Hungary). These bisepoxide-activated derivatives of the M540 hollow silica microspheres were prepared according to a previously published method [55]. Amano Lipase PS (lipase from Burkholderia cepacia, EC 3.1.1.3) for immobilization experiments was obtained from Sigma-Aldrich (Saint Louis, MO, USA).

\subsection{Analytical methods}

Gas chromatography (GC) analyses were carried out on Agilent 4890 instrument equipped with FID detector and a Hydrodex $\beta$-6TBDM column $(25 \mathrm{~m} \times 0.25 \mathrm{~mm} \times 0.25 \mu \mathrm{m}$ film with heptakis-(2,3-di- $O$-methyl-6- $O$-t-butyldimethylsilyl)- $\beta$-cyclodextrin; Macherey \& Nagel) using $\mathrm{H}_{2}$ as carrier gas (injector: $250{ }^{\circ} \mathrm{C}$, FID detector: $250{ }^{\circ} \mathrm{C}$, head pressure: $12 \mathrm{psi}, 50: 1 \mathrm{split}$ ratio, oven: $\left.120^{\circ} \mathrm{C}, 8 \mathrm{~min}\right)$.

GC: $t_{R}(\mathrm{~min})$ for rac-1: $4.0[(S)-2], 4.4[(R)-2], 5.8[(R)-$ 1], $6.0[(S)-1]$.

To characterize the productivity of the biocatalysts, specific reaction rate (or specific biocatalyst activity) in batch reactions $\left(r_{\text {batch }}\right)$ was calculated using the formula $r_{\text {batch }}=n_{(R)-2} /\left(t \times m_{B}\right)$ (where $n_{(R)-2}(\mu \mathrm{mol})$ is the amount of the product, $t$ ( $\mathrm{min})$ is the reaction time and $m_{B}(\mathrm{~g})$ is the mass of the applied biocatalyst). Specific reaction rates in continuous-flow systems $\left(r_{\text {flow }}\right)$ were calculated using the formula $r_{\text {flow }}=([(R)-2] \times v) / m_{B}$ (where $[(R)-2]$ $\left(\mu \mathrm{mol} \mathrm{mL} L^{-1}\right)$ is the molar concentration of the product $(R)-\mathbf{2}$, $\left.v(\mathrm{~mL} \mathrm{~min})^{-1}\right)$ is the flow rate and $m_{B}(\mathrm{~g})$ is the mass of the applied biocatalyst) [56].

\subsection{Scanning electron microscopy (SEM)}

The structure and morphology of the SNPs were investigated with a JEOL JSM-5500LV scanning electron microscope. Samples were prepared by placing some silica support on a copper grid coated with carbon and coated with gold prior to analysis. Electron beam energy of 20-22 kV was used.

\subsection{Preparation of activated supports}

Surface activation of M540 was carried out by suspending $300 \mathrm{mg}$ of support in $16 \mathrm{~mL}$ of $2.5 \%(\mathrm{v} / \mathrm{v})$ of activating agent (GA) in phosphate buffer $(100 \mathrm{mM}, \mathrm{pH} 7.5)$. The suspension was kept shaken at room temperature (RT) for overnight, followed by washing with phosphate buffer $(3 \times 20 \mathrm{~mL}, 100 \mathrm{mM}, \mathrm{pH} 7.5)$ for glutaraldehyde activated supports. The modified support was then dried at RT and stored at $4{ }^{\circ} \mathrm{C}$.

\subsection{Enzyme immobilization onto activated supports}

$150 \mathrm{mg}$ of various supports (M540, M540-GA, M540PDE, M540-NPE, M540-CDE, M540-GDE, M540HDDE and M540-GTGE) were suspended in phosphate buffer (15 mL, $100 \mathrm{mM}, \mathrm{pH} 7.5)$ containing $2 \mathrm{mg} / \mathrm{ml}$ of Lipase PS. The suspension was shaken overnight at room temperature (RT). After that, the suspension was washed three times with phosphate buffer $(10 \mathrm{~mL}, 100 \mathrm{mM}$, $\mathrm{pH} 7.5$ ) and stored at $4{ }^{\circ} \mathrm{C}$.

\subsection{Evaluation of the catalytic properties of Lipase PS biocatalysts}

Free or immobilized Lipase PS (25 mg) was added to the solution of the racemic 1-phenylethanol (rac-1, $\left.48 \mathrm{mg} \mathrm{mL}^{-1}\right)$ and vinyl acetate (2.76 equiv.) in $n$-hexane:MTBE 2:1 (v/v, $1 \mathrm{~mL}$ ), and the resulting mixture was shaken at $30^{\circ} \mathrm{C}$ in a sealed glass vial at $750 \mathrm{rpm}$.

For GC analyses, samples $(25 \mu \mathrm{L}$, diluted with ethanol $[975 \mu \mathrm{L}])$ were taken directly from the reaction mixture after $0.5,1,2,4 \mathrm{~h}$ and analyzed by GC.

\subsection{Reuse of Lipase PS biocatalysts}

The immobilized biocatalysts $(50 \mathrm{mg})$ was added to the solution of 1-phenylethanol (rac-1, $48 \mathrm{mg} \mathrm{mL}^{-1}$ ) and vinyl acetate (2.76 equiv.) in $n$-hexane:MTBE 2:1 (v/v, $2 \mathrm{~mL}$ ), and the resulting mixture was shaken at $30{ }^{\circ} \mathrm{C}$ in a sealed $4 \mathrm{~mL}$ 
glass vial at $750 \mathrm{rpm}$ for $1 \mathrm{~h}$. Samples $(25 \mu \mathrm{L})$ were taken after $1 \mathrm{~h}$ and after dilution with ethanol $(975 \mu \mathrm{L})$ analyzed by GC. After one reaction cycle, the Lipase PS preparations were centrifuged at $3000 \mathrm{rpm}$ at RT and supernatant was removed. Then, it was washed with 2-propanol $(5 \mathrm{~mL})$, phosphate buffer $(5 \mathrm{~mL}, 100 \mathrm{mM}, \mathrm{pH} 7.5)$, 2-propanol $(5 \mathrm{~mL})$ and $\mathrm{n}$-hexane $(5 \mathrm{~mL})$. Between each washing step immobilized enzymes were centrifuged at $3000 \mathrm{rpm}$ at RT and at the end dried at RT. The reactions were repeated with each biocatalyst in 5 cycles under identical conditions (keeping the proportion of the components constant).

\subsection{Continuous-flow kinetic resolution of racemic 1-phenylethanol (rac-1) with immobilized Lipase PS biocatalysts}

Continuous-flow kinetic resolutions were performed in a laboratory scale flow reactor, which comprised an HPLC pump (Knauer, Azura 4.1S), a packed-bed CatCart ${ }^{\mathrm{TM}}$ column (stainless steel, inner diameter: $4 \mathrm{~mm}$; total length: $70 \mathrm{~mm}$; packed length: $65 \mathrm{~mm}$; inner volume: $0.816 \mathrm{~mL}$ ) filled with immobilized Lipase PS biocatalyst (filling weights: M540-PDE-PS: $291.2 \mathrm{mg}\left(30-60^{\circ} \mathrm{C}\right), 282.0 \mathrm{mg}$ $\left(70{ }^{\circ} \mathrm{C}\right), 285.6 \mathrm{mg}\left(80^{\circ} \mathrm{C}\right), 255.7 \mathrm{mg}\left(90^{\circ} \mathrm{C}\right)$ and $260.4 \mathrm{mg}$ $\left(100^{\circ} \mathrm{C}\right)$; for Lipobond PS, $302.8 \mathrm{mg}\left(30-60^{\circ} \mathrm{C}\right), 310.3 \mathrm{mg}$ $\left(70{ }^{\circ} \mathrm{C}\right), 308.6 \mathrm{mg}\left(80^{\circ} \mathrm{C}\right), 326.4 \mathrm{mg}\left(90^{\circ} \mathrm{C}\right)$ and $319.9 \mathrm{mg}$ $\left.\left(100{ }^{\circ} \mathrm{C}\right)\right)$ placed into an in-house made multicolumn thermostated aluminum metal block holder with precise temperature control (Lauda, Alpha RA8).

The solution of rac-1 $\left(0.398\right.$ M. i.e. $\left.48 \mathrm{mg} \mathrm{mL}^{-1}\right)$ and vinyl acetate (2.76 equiv.) in dry toluene was pumped through the column filled with immobilized Lipase PS thermostated to various temperatures $\left(30-100{ }^{\circ} \mathrm{C}\right.$ in $10{ }^{\circ} \mathrm{C}$ steps) at a flow rate of $0.30 \mathrm{~mL} \mathrm{~min}^{-1}$. At each temperature samples were analyzed by GC at every $10 \mathrm{~min}$ up to $40 \mathrm{~min}$ after the start of the experiment. After a stationary operation was established (40 min after the start of the experiment) samples $(25 \mu \mathrm{L})$ were collected, diluted with ethanol to $1 \mathrm{~mL}$ and analyzed as described in Section 2.2. After a series of experiments, columns were washed with toluene $\left(0.5 \mathrm{~mL} \mathrm{~min}{ }^{-1}, 30 \mathrm{~min}\right)$ and stored in refrigerator $\left({ }^{\circ} \mathrm{C}\right)$.

\section{Results and discussion}

In the first set of experiments, six bisepoxides with linkers of different lengths, rigidity and hydrophobicity were selected for surface modification of M540 a support material with good adsorption properties. As reference, untreated M540 was used for comparison with adsorption immobilization of Lipase PS [48, 57]. M540 activated with glutaraldehyde (M540-GA) was also included for further comparison with covalent binding. After pre-activation, immobilization of Lipase PS was carried out from the commercially available enzyme powder.

Activity and selectivity of the immobilized biocatalysts were compared with the free enzyme powder by means of the enantiomer selective acylation of racemic 1-phenylethanol (rac-1) (Fig. 1). The reaction was characterized by the specific reaction rate $\left(r_{\text {batch }}\right)$, conversion of the substrate $(c)$, and enantiomeric excess of the product $\left(e e_{(R)-2}\right)$ (Table 1) [56].

As it can be gleaned from Table 1, the unmodified form of Lipase PS powder exhibited high activity $\left(r_{\text {batch }}=\right.$ $9.0 \mathrm{U} / \mathrm{g})$ and selectivity $\left(e e_{(R)-2}=98.9 \%\right)$. In the present study, our objective was to improve these properties by means of various modes of immobilization. Our experiments provided the following findings:

1. Immobilization by adsorption onto unmodified porous hollow silica microspheres (M540) with vinyl and amino functional groups on their surface resulted in high adsorption efficiency of the enzyme to the support (M540-PS).

2. Amino groups of M540 were activated using bifunctional compounds to fix the enzyme by means of stable covalent bonds. Glutaraldehyde (GA) the most often used amino-group activator, is very effective but also expensive and being a strong disinfectant is toxic and irritant. By using bisepoxides as amino group activators the drawbacks of GA can be avoided.

The epoxide functions of the activating agent can form covalent bonds under mild conditions not only with the amine functions of lysine exposed on the surface (see

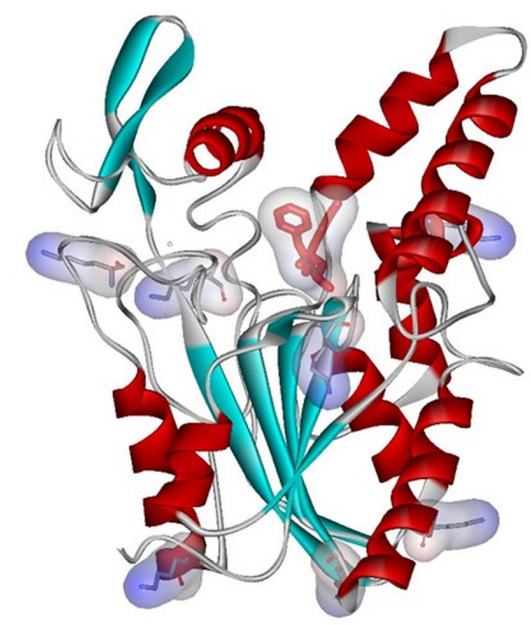

Fig. 2 Secondary structure of Lipase PS with surface exposed lysines adopted from [48] 
Table 1 Catalytic properties of the free and immobilized Lipase PS in kinetic resolution of $\mathrm{rac}-\mathbf{1}$ after $1 \mathrm{~h}$ reaction time

\begin{tabular}{lccc}
\hline Sample & $\begin{array}{c}c \\
{[\%]}\end{array}$ & $\begin{array}{c}e e_{(R)-2} \\
{[\%]}\end{array}$ & $\begin{array}{c}r_{\text {batch }} \\
{[\mathrm{Unit} / \mathrm{g}]}\end{array}$ \\
\hline Free Lipase PS & $13.0 \pm 0.51$ & $98.9 \pm<0.1$ & $9.0 \pm 1.07$ \\
M540-PS & $5.7 \pm 0.27$ & $98.5 \pm<0.1$ & $3.9 \pm 0.56$ \\
M540-GA-PS & $1.5 \pm 0.68$ & $94.8 \pm 2.3$ & $3.5 \pm 1.42$ \\
M540-PDE-PS & $20.3 \pm 1.04$ & $99.1 \pm<0.1$ & $42.8 \pm 2.18$ \\
M540-NPE-PS & $5.5 \pm 1.11$ & $98.7 \pm<0.1$ & $12.5 \pm 2.33$ \\
M540-GDE-PS & $6.1 \pm 0.29$ & $98.6 \pm<0.1$ & $14.0 \pm 0.60$ \\
M540-CDE-PS & $11.4 \pm 0.50$ & $98.6 \pm<0.1$ & $26.1 \pm 1.05$ \\
M540-HDDE-PS & $15.8 \pm 1.17$ & $99.1 \pm<0.1$ & $36.3 \pm 2.45$ \\
M540-GTGE-PS & $2.6 \pm 0.75$ & $97.4 \pm 1.2$ & $5.9 \pm 1.57$ \\
\hline
\end{tabular}

Reaction conditions: $25 \mathrm{mg}$ free or immobilized Lipase PS biocatalyst, $1 \mathrm{~mL}$-hexane/MTBE 2/1, rac-1 (0.398 M. i.e. $\left.48 \mathrm{mg} \mathrm{mL}^{-1}\right)$ and vinyl acetate (2.76 equiv.)

Fig. 2), but also with thiol and carboxylate groups [19].

Thus, covalent bond formation ability of the epoxy-activated supports can be higher than those activated with the glutaraldehyde. This can explain the higher activity of Lipase PS immobilized onto the bisepoxide-activated supports as compared to those related with glutaraldehyde (Table 1).

We found that out of the six activating agents applied, the one treated with the poly(ethylene glycol) diglycidyl ether (PDE) bisepoxide improved best the catalytic properties of the immobilized Lipase PS. PDE being a bisepoxide with a long and flexible linker is capable to fix the enzyme via multipoint attachment in the proper orientation. In fact, compared to the free enzyme $\left(r_{\text {batch }}=9.0 \mathrm{U} / \mathrm{g}\right.$ and $e e_{(R)-2}=$ $98.9 \%)$ the biocatalyst M540-PDE-PS showed both improved selectivity $\left(e e_{(R)-2}=99.1 \%\right)$ and activity $\left(r_{\text {batch }}=\right.$ $42.8 \mathrm{U} / \mathrm{g}$ ). In previous study, the bioimprinting effect of different additives on biocatalytic properties was investigated during immobilization of Lipase PS by adsorption. The most active preparation was the adsorbed Lipase PS / PEG 20k biocatalyst, which had an enzyme activity of $r_{\text {batch }}=20.5 \mathrm{U} / \mathrm{g}$ and $e e_{(R)-2}$ of 99.0 in acylation of rac-1a after $4 \mathrm{~h}$ reaction time. Furthermore, a mesoporous silica gel (Dv250) grafted with (3-aminopropyl)trimethoxysilane (APTMOS) and phenyltrimethoxysilane (PTMOS) at 1:3 ratio was selected as carrier to perform the adsorption and covalent immobilization of Lipase PS in the presence of seven different additives using GDE as cross-linking agent. The results of GDE cross-linking after adsorption of Lipase PS without additives were discouraging because the resulted preparations exhibited almost no activity in KRs of rac-1a (only $0.3 \%$ conversion after $24 \mathrm{~h}$ ). The best results were achieved with PVA $18-88$ ( $c=14.0 \%$ after 24 h) [27]. The good results with PDE activated support may be rationalized by envisaging the spatial disposition of the surface exposed lysine residues in the open conformation of Lipase PS (Fig. 2). The structure shown in Fig. 2 clearly indicates that the majority of the lysine residues (four out of seven) exposed on the surface are close to the lid domains modulating accessibility of the active site. Thus, anchoring the enzyme involving these residues may obstruct - at least partially - the entrance to the active site leading to inactive forms of the biocatalyst. This effect can be reduced or even eliminated by using a longer and flexible bifunctional linker. When the length of the linker region of the applied bisepoxide was shortened, activity of Lipase PS fixed to the bisepoxide-activated M540 carrier decreased. Glycerol triglycidyl ether (GTGE) is a trisepoxide with ability to form simultaneously bounds with three amino groups generating thereby three attachment points. Note, however that this feature does not necessarily guarantee that a carrier activated in this way is superior to those activated with bisepoxides. Among the covalently bound forms the support activated with GA (coded M540GA-PS) offered a Lipase PS biocatalyst of lowest activity $\left(r_{\text {batch }}=3.5 \mathrm{U} / \mathrm{g}\right)$ and selectivity $\left(e e_{(R)-2}=94.8 \%\right)$. This form proved to be inferior even to the absorbed form (Table 1).

\subsection{Enzyme loading capacity of the M540-PDE support}

When enzymes are immobilized on a surface, the biological activity of the protein depends on how "crowded" the surface is. Initially, specific activity of the immobilized biocatalyst increases as more and more enzyme molecules are fixed onto the surface. After reaching an optimum, the activity starts decline with increasing enzyme density. Accordingly, for maximizing enzyme loadings, a large surface area is advantageous. Porous silica materials allow high loading density with only slight limitation of mass transfer [58].

As the best support for Lipase PS proved to be M540PDE, therefore it was this support, which was selected for detailed study on enzyme loading capacity. At optimum, the highest biocatalytic activity can be achieved with the lowest amount of the valuable enzyme. To optimize enzyme loading in the course of immobilization of Lipase PS on M540-PDE, different enzyme / M540-PDE ratios were examined. To $50 \mathrm{mg}$ of M540-PDE, successively increasing amounts of Lipase PS (from 1 to $15 \mathrm{mg}$ ) were added (Fig. 3). Immobilization yield $\left(Y_{I}\right)$ was also determined according to the equation $Y_{I}=\left([P]_{0}-[P]\right) /[P]_{0}^{*} 100[\%]$ 


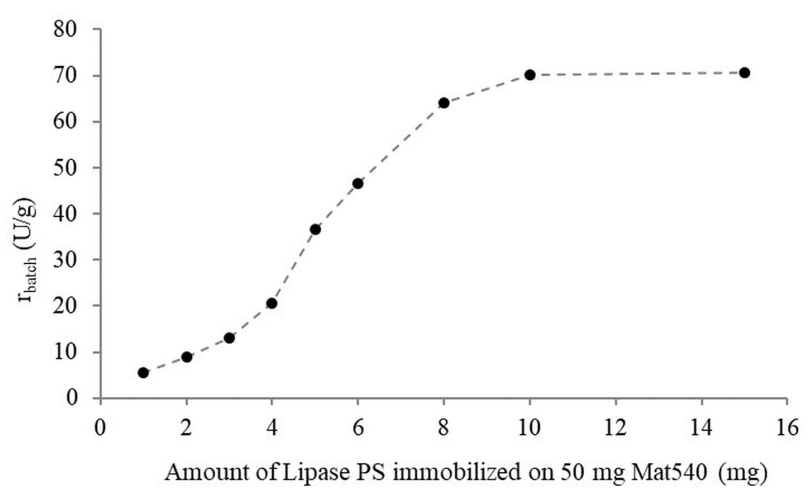

Fig. 3 Enzyme loading capacity of PDE activated M540 (tested with kinetic resolution of $\mathrm{rac}-\mathbf{1}$; reaction time: $1 \mathrm{~h}$ ).

by using Bradford assay to determine the protein concentration of the supernatant before the immobilization $[P]_{0}$ and after the immobilization $[P]$ [59]. In all cases the $Y_{I}$ was $100 \%$, which shows the high adsorption efficiency of amino and vinyl functionalized M540 (data not shown). Next to $Y_{I}$ catalytic properties of the formed biocatalysts were tested in kinetic resolution of racemic 1-phenylethanol using vinyl acetate as acylating agents. As Fig. 3 shows specific activity of the immobilized biocatalyst increased with increasing amount of Lipase PS up to $10 \mathrm{mg}$, beyond this value enzyme activity remained constant. As the $Y_{I}$ was constant at all concentrations, in further experiments the optimal enzyme loading i.e. Lipase PS/M540-PDE 1/5 was used. In an immobilized enzyme, there are several possible effects of enzyme crowding. The crowding may reduce enzyme mobility because the chain of one enzyme will crash versus the protein molecules surrounding it, and perhaps may increase the enzyme stability [60].

\subsection{Reusability of Lipase PS biocatalysts}

Mechanical and chemical (operational) stability are among the most important features of a biocatalyst. In order to compare their reusability and catalytic stability in a multi-cycle process, Lipase PS biocatalysts (M540-PDE-PS and M540-PS) were selected as a model for kinetic resolution (KR) of rac-1 (Fig. 4). After each cycle, the Lipase PS biocatalysts were washed (see Section 2.6) and reused in 5 repetitive reaction cycles. Usually, it is considered that an enzyme can be reused until its activity drops to less than $25 \%$ of its initial value [47]. Fig. 4 shows the retained relative specific activities of the tested biocatalysts related to their initial specific biocatalyst activity as $100 \%$.

Our covalently fixed M540-PDE-PS biocatalyst proved to be remarkably durable in the recycling tests, retaining after 5 cycles over $60 \%$ of its initial activity

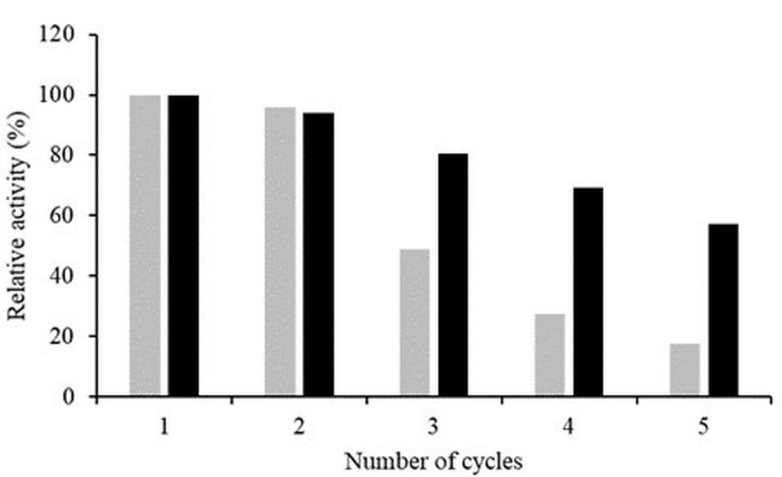

Fig. 4 Reusability of the immobilized Lipase PS biocatalysts in kinetic resolution of $\mathbf{r a c} \mathbf{- 1}$ (reaction time: 1 h). $\mathbf{\square}$ : M540-PDE-PS; $\mathbf{\square}$ : M540-PS

$\left(r_{\text {batch }}=61.3 \mathrm{U} / \mathrm{g}\right)$ (Fig. 4). The adsorptively-fixed M540-PS preparation was less durable $(<20 \%$ residual activity after 5 cycles), supposedly due to the weaker interaction between enzyme and support. M540-PS is a preparation made by adsorption, thus enzyme leaking can occur during the washing steps, which can lead to reduced enzyme activity. These results show stronger interaction of the enzyme with the support activated with PDE, but maybe incorrect elimination of the remaining compounds during the washing steps, which led to almost $40 \%$ activity decrease after 5 cycles [61].

Morphology of the M540-PDE-PS was investigated by scanning electron microscopy (SEM) before use and after the recycling (Fig. 5). SEM investigations of M540-PDE-PS before its use in biotransformations shows intact morphology of spherical beads with diameters 10-50 $\mu \mathrm{m}$ (Fig. 5A), and an absence of mechanical damage caused by the bisepoxide activation and enzyme immobilization steps. The preparation demonstrated mechanical stability and durability as it remained intact after 5 cycles of KR experiments in batch mode (Fig. 5B).

\subsection{Comparison of the productivity and selectivity of Lipase PS biocatalysts in continuous-flow mode kinetic resolution of rac-1 at different temperatures}

Catalytic performance of our best Lipase PS biocatalyst (M540-PDE-PS) was compared to the commercially available Lipobond Lipase PS, which is a lipase from Burkholderia cepacia covalently immobilized on acrylic / polystyrene resin $(150-700 \mu \mathrm{m})$. A lab scale reactor system equipped with packed-bed stainless steel columns (CatCart ${ }^{\mathrm{TM}}$ ) was used, enabling precise temperature and flow rate control.

The two Lipase PS biocatalysts were packed into columns and used for KR of rac-1 with vinyl acetate as 


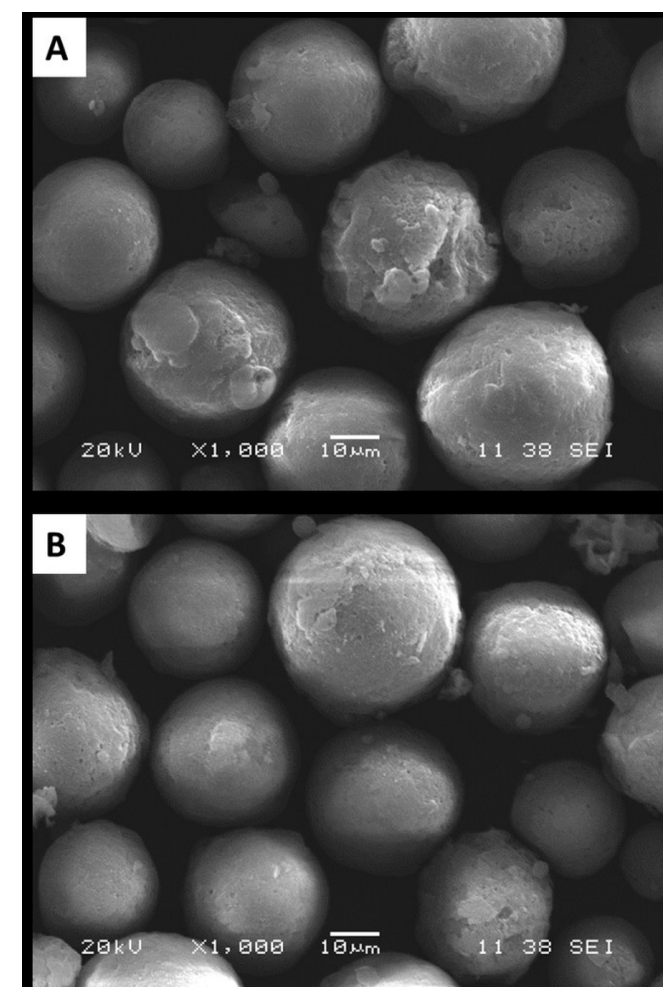

Fig. 5 Scanning electron microscopy (SEM) analysis of M540-PDE-PS: (A) before kinetic resolution of $\mathrm{rac}-1$; (B) after 5 cycles of KRs in batch

acylating agent in toluene, while raising the temperature from 30 to $100{ }^{\circ} \mathrm{C}$ in increments of $10{ }^{\circ} \mathrm{C}$ at a constant flow rate of $0.30 \mathrm{~mL} \mathrm{~min}^{-1}$. Productivity $\left(r_{\text {flow }}\right)$ and enantiomeric excess $\left(e e_{(R)-2}\right)$ values of the product were plotted as a function of temperature (Fig. 6). The stability of the two preparations depend on the immobilization strategy [62-64]. In the case of Lipobond Lipase PS, the specific reaction rate increased significantly up to $50{ }^{\circ} \mathrm{C}$, being the optimal temperature $\left(r_{\text {flow }}=157.4 \mathrm{U} / \mathrm{g}\right)$ for this biocatalyst. Specific reaction rate of M540-PDE-PS was somewhat lower that for Lipobond Lipase PS between 30 and $60^{\circ} \mathrm{C}$, but increasing productivity could be observed up to $70{ }^{\circ} \mathrm{C}$, where M540-PDE-PS had its temperature optimum $\left(r_{\text {flow }}=127.3 \mathrm{U} / \mathrm{g}\right)$ and exhibited an almost twofold $r_{\text {flow }}$ value as Lipobond Lipase PS. At 80 and $90{ }^{\circ} \mathrm{C}$ M540-PDE-PS proved to be more resistant to the high temperatures, than Lipobond Lipase PS. At $100{ }^{\circ} \mathrm{C}$ both forms retained only about $20 \%$ of their initial activity. During incubation of the enzyme at high temperature, internal hydrophobic pockets of the enzyme may be on the reversible in the outside. If these hydrophobic groups may interact with other hydrophobic pockets of other enzymes, the reversibility of these conformational movements may be prevented and the stability of the enzyme will be decreased [60].

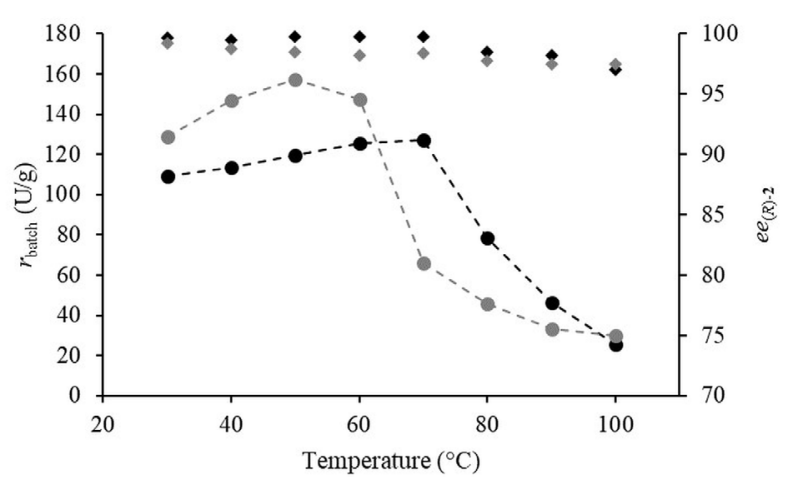

Fig. 6 Continuous-flow kinetic resolution of $\mathrm{rac}-\mathbf{1}$ at different temperatures with M540-PDE-PS and Lipobond Lipase PS $\left[r_{\text {flow }}\right.$ values of M540-PDE-PS $(\bullet)$ and Lipobond Lipase PS (•), $e e_{(R)-2}$ values of M540-PDE-PS ( $\bullet$ and Lipobond Lipase PS ( $\bullet$ ]

The other crucial feature of enzyme catalyzed reactions is stereoselectivity, permitting the production of chiral molecules in high enantiopurity. As it is shown in Fig. 6, the enantiomeric excess of the product $\left(e e_{(R)-2}\right)$ decreased with increasing temperature with both immobilized Lipase PS preparations over the entire temperature range covered, but even at $100{ }^{\circ} \mathrm{C}$ the $e e_{(R)-2}$ values remained above $97 \%$. Also up to $90{ }^{\circ} \mathrm{C}$, however, the $e e_{(R)-2}$ values obtained with M540-PDE-PS were higher than those produced with Lipobond Lipase PS. It was already demonstrated that operational stability of immobilized lipases in continuous-flow kinetic resolutions at the optimum temperature are quite high and stationary reaction conditions could be maintained even for one week period $[17,65,66]$.

Because the main goal of this study was to demonstrate the effect of using difference activating agents and not to produce large quantities of the already known product $((R)$ 2a), no further attempts were made for their preparative production. However, M540-PDE-PS was compared with other Lipase PS preparations using different materials. The results are shown in Table 2. Compared with other immobilized lipases, Lipase PS-carbon nanotube has a higher reaction speed which can be due to the physical adsorption. This immobilization method has less effect to the enzyme distortion and loss of activity [72]. But owing to the weak interaction between enzyme and carrier, enzyme leakage may happen during each batch of the reactions which will cause pollution to the products. However, covalent bonding used in this study can avoid such problems as we mentioned above. Storage stability of the freshly prepared M540-PDE-PS was tested after three months of storage at $4{ }^{\circ} \mathrm{C}$. It showed less than $5 \%$ loss of biocatalytic activity with unchanged $e e_{(R)-2}$ (data not shown). 
Table 2 A comparison between the M540-PDE-PS and the other immobilized lipase from Burkholderia cepacia

\begin{tabular}{|c|c|c|c|c|c|}
\hline Immobilization support & $\begin{array}{c}\mathrm{c} \\
{[\%]}\end{array}$ & $\begin{array}{l}e e_{(R)-2} \\
(\%)\end{array}$ & $\begin{array}{l}\text { Reaction } \\
\text { time }\end{array}$ & $\begin{array}{c}\text { Specific productivity } \\
\left(\% \%_{\text {conversion }} / \mathrm{min}^{*} \mathrm{mg} \text { biocatalyst }\right)\end{array}$ & References \\
\hline Modified multi-walled carbon nanotube & 50 & 99 & $10 \mathrm{~min}$ & 0.050 & {$[67]$} \\
\hline Macroporous resin NKA & 50 & 99 & $30 \mathrm{~min}$ & 0.017 & [68] \\
\hline Microgel & 35.1 & 98 & $5 \mathrm{~h}$ & 0.012 & [69] \\
\hline Zirconia particles & 49.9 & 99.9 & $48 \mathrm{~h}$ & $3.47 \times 10^{-4}$ & {$[70]$} \\
\hline Carboxyl-functionalized meso cellular foams & 50 & 99 & $48 \mathrm{~h}$ & $1.74 \times 10^{-4}$ & {$[71]$} \\
\hline Lipobond & 19.6 & 99 & $60 \mathrm{~min}$ & 0.013 & This study \\
\hline M540-PDE & 20.3 & 99 & $60 \mathrm{~min}$ & 0.014 & This study \\
\hline
\end{tabular}

\section{Conclusion}

Successful covalent immobilization of Lipase PS was demonstrated on hollow silica microspheres having polar and nonpolar functions on their surface (M540), after activating with various bisepoxides. Out of the six different bisepoxides used as activating agents, poly(ethylene glycol) diglycidyl ether (PDE) characterized by a relatively long and flexible linker region proved to be the most successful for immobilization of Lipase PS at 1/5 enzyme / support ratio as optimal loading. Kinetic resolution and reusability studies based on acetylation of racemic 1-phenylethanol (rac1) indicated that bisepoxide-activated M540 carrier provided a suitable micro-environment for the enzyme during catalysis. M540-PDE-PS exhibiting high specific activity $\left(r_{\text {batch }}=42.8 \mathrm{U} / \mathrm{g}\right)$ and enantiomer selectivity $\left(e e_{(R)-2}=99.1 \%\right)$ was used in a continuous-flow reactor and compared with a

\section{References}

[1] Bornscheuer, U. T. "Immobilizing Enzymes: How to Create More Suitable Biocatalysts", Angewandte Chemie International Edition, 42(29), pp. 3336-3337, 2003.

https://doi.org/10.1002/anie.200301664

[2] Poppe, L., Novák, L. "Selective Biocatalysis: A Synthetic Approach", Verlag Chemie, Weinheim-New York, 1992.

[3] Schoemaker, H. E., Mink, D., Wubbolts, M. G. "Dispelling the Myths - Biocatalysis in Industrial Synthesis", Science, 299(5613), pp. 1694-1697, 2003.

https://doi.org/10.1126/science.1079237

[4] Reetz, M. T. "Biocatalysis in Organic Chemistry and Biotechnology: Past, Present, and Future", Journal of the American Chemical Society, 135(34), pp. 12480-12496, 2013. https://doi.org/10.1021/ja405051f

[5] Bommarius, A. S., Paye, M. F. "Stabilizing biocatalysts", Chemical Society Reviews, 42(15), pp. 6534-6565, 2013. https://doi.org/10.1039/c3cs60137d

[6] Kumar, A., Venkatesu, P. "Overview of the Stability of $\alpha$-Chymotrypsin in Different Solvent Media", Chemical Reviews, 112(7), pp. 4283-4307, 2012. https://doi.org/10.1021/cr2003773 commercially available covalently immobilized Lipase PS. In thermal stability tests, at lower temperatures $\left(30-60{ }^{\circ} \mathrm{C}\right)$ M540-PDE-PS was slightly less active but more selective than Lipobond Lipase PS. At higher temperatures (70$90{ }^{\circ} \mathrm{C}$ ) M540-PDE-PS showed higher activity and selectivity than the commercial PS preparation. These results open up the possibility to apply this novel form of Lipase PS for industrial applications e.g. for biodiesel production.

\section{Acknowledgement}

The authors thank to Materium Innovations (Granby, Canada) for M540 silica supports. This work was supported by the Higher Education Excellence Program of the Ministry of Human Capacities in the frame of Biotechnology research area of Budapest University of Technology and Economics (BME FIKP-BIO).

[7] Sheldon, R. A. "Enzyme Immobilization: The Quest for Optimum Performance", Advanced Synthesis and Catalysis, Special Issue: Biocatalysis, 349(8-9), pp. 1289-1307, 2007. https://doi.org/10.1002/adsc.200700082

[8] Sheldon, R. A., van Pelt, S. "Enzyme Immobilisation in Biocatalysis: Why, What and How", Chemical Society Reviews, 42(15), pp. 6223-6235, 2013.

https://doi.org/10.1039/c3cs60075k

[9] Mohamad, N. R., Marzuki, N. H. C., Buang, N. A., Huyop, F., Wahab, R. A. "An overview of technologies for immobilization of enzymes and surface analysis techniques for immobilized enzymes", Biotechnology and Biotechnological Equipment, 29(2), pp. $205-220,2015$. https://doi.org/10.1080/13102818.2015.1008192

[10] Hanefeld, U., Gardossi, L., Magner, E. "Understanding enzyme immobilisation", Chemical Society Reviews, 38(2), pp. 453-468, 2009. https://doi.org/10.1039/B711564B

[11] Datta, S., Christena, L. R., Rajaram, Y. R. S. "Enzyme immobilization: an overview on techniques and support materials", 3 Biotech, 3(1), pp. 1-9, 2013. https://doi.org/10.1007/s13205-012-0071-7 
[12] Brena, B., González-Pombo, P., Batista-Viera, F. "Immobilization of Enzymes: A Literature Survey", In: Guisan, J. (ed.) Immobilization of Enzymes and Cells, Methods in Molecular Biology (Methods and Protocols), Vol. 1051, Humana Press, Totowa, NJ, 2013, pp. 15-31.

https://doi.org/10.1007/978-1-62703-550-7_2

[13] Galvão, W. S., Pinheiro, B. B., Golçalves, L. R. B., de Mattos, M. C., Fonseca, T. S., Regis, T., Zampieri, D., dos Santos, J. C. S., Costa, L. S., Correa, M. A., Bohn, F., Fechine, P. B. A. "Novel nanohybrid biocatalyst: application in the kinetic resolution of secondary alcohols", Journal of Materials Science, 53(20), pp. 1412114137, 2018

https://doi.org/10.1007/s10853-018-2641-5

[14] Pinheiro, M. P., Rios, N. S., Fonseca, T. S., Bezerra, F. A., Rodríguez-Castellón, E., Fernandez-Lafuente, R., de Mattos, M. C., dos Santos, J. C. S., Gonçalves, L. R. B. "Kinetic resolution of drug intermediates catalyzed by lipase B from Candida antarctica immobilized on Immobead-350", Biotechnology Progress, 34(4), pp. 878-889, 2018.

https://doi.org/10.1002/btpr.2630

[15] Melo, A. D. Q., Silva, F. F. M., dos Santos, J. C. S., FernándezLafuente, R., Lemos, T. L. G., Dias Filho, F. A. "Synthesis of Benzyl Acetate Catalyzed by Lipase Immobilized in Nontoxic ChitosanPolyphosphate Beads", Molecules, 22(12), pp. 2165-2185, 2017. https://doi.org/10.3390/molecules22122165

[16] dos Santos, J. C. S., Bonazza, H. L., de Matos, L. J. B. L., Carneiro, E. A., Barbosa, O., Fernandez-Lafuente, R., Gonçalves, L. R. B., de Sant' Ana, H. B., Santiago-Aguiar, R. S. "Immobilization of CALB on activated chitosan: Application to enzymatic synthesis in supercritical and near-critical carbon dioxide", Biotechnology Reports, 14, pp. 16-26, 2017.

https://doi.org/10.1016/j.btre.2017.02.003

[17] Weiser, D., Nagy, F., Bánóczi, G., Oláh, M., Farkas, A., Szilágyi, A., László, K., Gellért, Á., Marosi, G., Kemény, S., Poppe, L. "Immobilization engineering - How to design advanced sol-gel systems for biocatalysis?", Green Chemistry, 19(16), pp. 3927-3937, 2017. https://doi.org/10.1039/C7GC00896A

[18] Weiser, D., Varga, A., Kovács, K., Nagy, F., Szilágyi, A. Vértessy, B. G., Paizs, C., Poppe, L. "Bisepoxide Cross-Linked Enzyme Aggregates - New Immobilized Biocatalysts for Selective Biotransformations", ChemCatChem, 6(5), pp. 1463-1469, 2014. https://doi.org/10.1002/cctc.201300806

[19] Weiser, D., Sóti, P. L., Bánóczi, G., Bódai, V., Kiss, B., Gellért, Á., Nagy, Z. K., Koczka, B., Szilágyi, A., Marosi, G., Poppe, L. "Bioimprinted lipases in PVA nanofibers as efficient immobilized biocatalysts", Tetrahedron, 72(46), pp. 7335-7342, 2016. https://doi.org/10.1016/j.tet.2016.06.027

[20] Boros, Z., Falus, P., Márkus, M., Weiser, D., Oláh, M., Hornyánszky, G., Nagy, J., Poppe, L. "How the mode of Candida antarctica lipase B immobilization affects the continuous-flow kinetic resolution of racemic amines at various temperatures", Journal of Molecular Catalysis B: Enzymatic, 85-86, pp. 119-125, 2013. https://doi.org/10.1016/j.molcatb.2012.09.004
[21] Bartha-Vári, J. H., Toşa, M. I., Irimie, F.-D., Weiser, D., Boros, Z., Vértessy, B. G., Paizs, C., Poppe, L. "Immobilization of Phenylalanine Ammonia-Lyase on Single-Walled Carbon Nanotubes for Stereoselective Biotransformations in Batch and Continuous-Flow Modes", ChemCatChem, 7(7), pp. 1122-1128, 2015. https://doi.org/10.1002/cctc.201402894

[22] Nagy-Györ, L., Boros, Z., Poppe, L. "Immobilization of lipases from Rhizomucor miehei and Thermomyces lanuginosus by adsorption on variously grafted silica gels", Periodica Polytechnica Chemical Engineering, 57(1-2), pp. 37-40, 2013.

https://doi.org/10.3311/PPch.2168

[23] Guzik, U., Hupert-Kocurek, K., Wojcieszyńska, D. "Immobilization as a Strategy for Improving Enzyme Properties-Application to Oxidoreductases", Molecules, 19(7), pp. 8995-9018, 2014. https://doi.org/10.3390/molecules19078995

[24] DiCosimo, R., McAuliffe, J., Poulose, A. J., Bohlmann, G. "Industrial use of immobilized enzymes", Chemical Society Reviews, 42(15), pp. 6437-6474, 2013. https://doi.org/10.1039/c3cs35506c

[25] Rios, N. S., Pinheiro, M. P., dos Santos, J. C. S., Fonseca, T. S., Lima, L. D., de Mattos, M. C., Freire, D. M. G., da Silva Júnior, I. J., Rodríguez-Aguado, E., Gonçalves, L. R. B. "Strategies of covalent immobilization of a recombinant Candida antarctica lipase B on pore-expanded SBA-15 and its application in the kinetic resolution of $(R, S)$-Phenylethyl acetate", Journal of Molecular Catalysis B: Enzymatic, 133, pp. 246-258, 2016. https://doi.org/10.1016/j.molcatb.2016.08.009

[26] Rodrigues, R. C., Hernandez, K., Barbosa, O., Rueda, N., GarciaGalan, C., dos Santos, J. C. S., Berenguer-Murcia, A., FernándezLafuente, R. "Immobilization of Proteins in Poly-StyreneDivinylbenzene Matrices: Functional Properties and Applications", Curent Organic Chemistry, 19(17), pp. 1707-1718, 2015. https://doi.org/10.2174/1385272819666150429231728

[27] Zdarta, J., Meyer, A. S., Jesionowski, T., Pinelo, M. "A General Overview of Support Materials for Enzyme Immobilization: Characteristics, Properties, Practical Utility", Catalysts, 8(2), pp. $92-118,2018$. https://doi.org/10.3390/catal 8020092

[28] Wang, W., Zhou, W., Li, J., Hao, D., Su, Z., Ma, G. "Comparison of covalent and physical immobilization of lipase in gigaporous polymeric microspheres", Bioprocess and Biosystems Engineering, 38(11), pp. 2107-2115, 2015. https://doi.org/10.1007/s00449-015-1450-3

[29] Zou, B., Hu, Y., Cui, F., Jiang, L., Yu, D., Huang, H. "Effect of surface modification of low cost mesoporous $\mathrm{SiO}_{2}$ carriers on the properties of immobilized lipase", Journal of Colloid and Interface Science, 417, pp. 210-216, 2014. https://doi.org/10.1016/j.jcis.2013.11.029

[30] Yuce-Dursun, B., Cigil, A. B., Dongez, D., Kahraman, M. V., Ogan, A., Demir, S. "Preparation and characterization of sol - gel hybrid coating films for covalent immobilization of lipase enzyme", Journal of Molecular Catalysis B: Enzymatic, 127, pp. $18-25,2016$. https://doi.org/10.1016/j.molcatb.2016.02.007 
[31] Cui, J., Jia, S., Liang, L., Zhao, Y., Feng, Y. "Mesoporous CLEAssilica composite microparticles with high activity and enhanced stability", Scientific Reports, 5, article number: 14203, 2015. https://doi.org/10.1038/srep14203

[32] dos Santos, J. C. S., Barbosa, O., Ortiz, C., Berenguer-Murcia, A., Rodrigues, R. C., Fernández-Lafuente, R. "Importance of the Support Properties for Immobilization or Purification of Enzymes", ChemCatChem, 7(16), pp. 2413-2432, 2015. https://doi.org/10.1002/cctc.201500310

[33] Mateo, C., Torres, R., Fernández-Lorente, G., Ortiz, C., Fuentes, M., Hidalgo, A., López-Gallego, F., Abian, O., Palomo, J. M., Betancor, L., Pessela, B. C. C., Guisan, J. M., Fernández-Lafuente, R. "Epoxy-Amino Groups: A New Tool for Improved Immobilization of Proteins by the Epoxy Method", Biomacromolecules, 4(3), pp. 772-777, 2003. https://doi.org/10.1021/bm0257661

[34] Grazú, V., Abian, O., Mateo, C., Batista-Viera, F., FernándezLafuente, R., Guisán, J. M. "Stabilization of enzymes by multipoint immobilization of thiolated proteins on new epoxy-thiol supports", Biotechnology and Bioengineering, 90(5), pp. 597-605, 2005. https://doi.org/10.1002/bit.20452

[35] Mateo, C., Grazu, V., Palomo, J. M., Lopez-Gallego, F., FernandezLafuente, R., Guisan, J. M. "Immobilization of enzymes on heterofunctional epoxy supports", Nature Protocols, 2(5), pp. 1022-1033, 2007.

https://doi.org/10.1038/nprot.2007.133

[36] Vasylieva, N., Barnych, B., Meiller, A., Maucler, C., Pollegioni, L., Lin, J.-S., Barbier, D., Marinesco, S. "Covalent enzyme immobilization by poly(ethylene glycol) diglycidyl ether (PEGDE) for microelectrode biosensor preparation", Biosensors and Bioelectronics, 26(10), pp. 3993-4000, 2011. https://doi.org/10.1016/j.bios.2011.03.012

[37] Abaházi, E., Lestál, D., Boros, Z., Poppe, L. "Tailoring the Spacer Arm for Covalent Immobilization of Candida antarctica Lipase B Thermal Stabilization by Bisepoxide-Activated Aminoalkyl Resins in Continuous-Flow Reactors", Molecules, 21(6), pp. 767-784, 2016. https://doi.org/10.3390/molecules21060767

[38] Abaházi, E., Sátorhelyi, P., Erdélyi, B., Vértessy, B. G., Land, H., Paizs, C., Berglund, P., Poppe, L. "Covalently immobilized Trp60Cys mutant of $\omega$-transaminase from Chromobacterium violaceum for kinetic resolution of racemic amines in batch and continuous-flow modes", Biochemical Engineering Journal, 132, pp. 270-278, 2018.

https://doi.org/10.1016/j.bej.2018.01.022

[39] Gotor-Fernández, V., Busto, E., Gotor, V. "Candida antarctica Lipase B: An Ideal Biocatalyst for the Preparation of Nitrogenated Organic Compounds", Advanced Synthesis and Catalysis, 348(7-8), pp. 797-812, 2006.

https://doi.org/10.1002/adsc.200606057

[40] Houde, A., Kademi, A., Leblanc, D. "Lipases and Their Industrial Applications: An Overview", Applied Biochemistry and Biotechnology, 118(1-3), pp. 155-170, 2004. https://doi.org/10.1385/ABAB:118:1-3:155

[41] Reetz, M. T. "Lipases as practical biocatalysts", Current Opinion in Chemical Biology, 6(2), pp. 145-150, 2002. https://doi.org/10.1016/S1367-5931(02)00297-1
[42] Angajala, G., Pavan, P., Subashini, R. "Lipases: An overview of its current challenges and prospectives in the revolution of biocatalysis", Biocatalysis and Agricultural Biotechnology, 7, pp. 257-270, 2016. https://doi.org/10.1016/j.bcab.2016.07.001

[43] Sánchez, D. A., Tonetto, G. M., Ferreira, M. L. "Burkholderia cepacia lipase: A versatile catalyst in synthesis reactions", Biotechnology and Bioengineering, 115(1), pp. 6-24, 2018. https://doi.org/10.1002/bit.26458

[44] Gog, A., Roman, M., Toşa, M., Paizs, C., Irimie, F. D. "Biodiesel production using enzymatic transesterification - Current state and perspectives", Renewable Energy, 39(1), pp. 10-16, 2012. https://doi.org/10.1016/j.renene.2011.08.007

[45] Bencze, L. C., Bartha-Vári, J. H., Katona, G., Toşa, M. I., Paizs, C., Irimie, F.-D. "Nanobioconjugates of Candida antarctica lipase B and single-walled carbon nanotubes in biodiesel production", Bioresource Technology, 200, pp. 853-860, 2016. https://doi.org/10.1016/j.biortech.2015.10.072

[46] Shah, S., Gupta, M. N. "Kinetic resolution of ( \pm )-1-phenylethanol in $[\mathrm{Bmim}]\left[\mathrm{PF}_{6}\right]$ using high activity preparations of lipases", Bioorganic and Medicinal Chemistry Letters, 17(4), pp. 921-924, 2007. https://doi.org/10.1016/j.bmcl.2006.11.057

[47] Ursoiu, A., Paul, C., Kurtán, T., Péter, F. "Sol-gel Entrapped Candida antarctica lipase B - A Biocatalyst with Excellent Stability for Kinetic Resolution of Secondary Alcohols", Molecules, 17(11), pp. 13045-13061, 2012.

https://doi.org/10.3390/molecules171113045

[48] Abaházi, E., Boros, Z., Poppe, L. "Additives Enhancing the Catalytic Properties of Lipase from Burkholderia cepacia Immobilized on Mixed-Function-Grafted Mesoporous Silica Gel", Molecules, 19(7), pp. 9818-9837, 2014.

https://doi.org/10.3390/molecules19079818

[49] Nagy, B., Galla, Z., Bencze, L. C., Toșa, M. I., Paizs, C., Forró, E., Fülöp, F. "Covalently Immobilized Lipases are Efficient Stereoselective Catalysts for the Kinetic Resolution of rac-(5Phenylfuran-2-yl)- $\beta$-alanine Ethyl Ester Hydrochlorides", European Journal of Organic Chemistry, 2017(20), pp. 2878-2882, 2017. https://doi.org/10.1002/ejoc.201700174

[50] dos Santos, J. C. S., Rueda, N., Gonçalves, L. R. B., FernandezLafuente, R. "Tuning the catalytic properties of lipases immobilized on divinylsulfone activated agarose by altering its nanoenvironment", Enzyme and Microbial Technology, 77, pp. 1-7, 2015. https://doi.org/10.1016/j.enzmictec.2015.05.001

[51] Fernandez-Lopez, L., Bartolome-Cabrero, R., Rodriguez M. D., dos Santos, C. S., Rueda, N., Fernandez-Lafuente, R. "Stabilizing effects of cations on lipases depend on the immobilization protocol", RSC Advances, 5(102), pp. 83868-83875, 2015.

https://doi.org/10.1039/C5RA18344H

[52] Verger, R., Mieras, M. C., de Haas, G. H. "Action of Phospholipase A at Interfaces", Journal of Biological Chemistry, 248(11), pp. 40234034, 1973.

[53] Bonazza, H. L., Manzo, R. M., dos Santos, J. C. S., Mammarella, E. J. "Operational and Thermal Stability Analysis of Thermomyces lanuginosus Lipase Covalently Immobilized onto Modified Chitosan Supports", Applied Biochemistry and Biotechnology, 184(1), pp. 182-196, 2017. https://doi.org/10.1007/s12010-017-2546-9 
[54] dos Santos, J. C. S., Rueda, N., Torres, R., Barbosa, O., Gonçalves, L. R. B., Fernandez-Lafuente, R. "Evaluation of divinylsulfone activated agarose to immobilize lipases and to tune their catalytic properties", Process Biochemistry, 50(6), pp. 918-927, 2015. https://doi.org/10.1016/j.procbio.2015.03.018

[55] Liu, Y., Guo, C., Sun, X.-T., Liu, C.-Z. "Improved performance of Yarrowia lipolytica lipase-catalyzed kinetic resolution of (R,S)2-octanol by an integrated strategy of interfacial activation, bioimprinting and immobilization", Bioresource Technology, 142, pp. 415-419, 2013. https://doi.org/10.1016/j.biortech.2013.05.045

[56] Csajági, C., Szatzker, G., Tőke, E. R., Ürge, L., Darvas, F., Poppe, L. "Enantiomer selective acylation of racemic alcohols by lipases in continuous-flow bioreactors", Tetrahedron: Asymmetry, 19(2), pp. 237-246, 2008. https://doi.org/10.1016/j.tetasy.2008.01.002

[57] Jesionowski, T., Zdarta, J., Krajewska, B. "Enzyme immobilization by adsorption: a review", Adsorption, 20(5-6), pp. 801-821, 2014. https://doi.org/10.1007/s10450-014-9623-y

[58] Gupta, M. N., Kaloti, M., Kapoor, M., Solanki, K. "Nanomaterials as Matrices for Enzyme Immobilization", Artificial Cells, Blood Substitutes, and Biotechnology, 39(2), pp. 98-109, 2011.

https://doi.org/10.3109/10731199.2010.516259

[59] Nagy, F., Tasnádi, G., Balogh-Weiser, D., Bell, E., Hall, M., Faber, K., Poppe, L. "Smart Nanoparticles for Selective Immobilization of Acid Phosphatases", ChemCatChem, 10(16), pp. 3490-3499, 2018 https://doi.org/10.1002/cctc.201800405

[60] Fernandez-Lopez, L., Pedrero, S. G., Lopez-Carrobles, N., Gorines, B. C., Virgen-Ortíz, J. J., Fernandez-Lafuente, R. "Effect of protein load on stability of immobilized enzymes", Enzyme and Microbial Technology, 98, pp. 18-25, 2017. https://doi.org/10.1016/j.enzmictec.2016.12.002

[61] Lage, F. A. P., Bassi, J. J., Corradini, M. C. C., Todero, L. M., Luiz, J. H. H., Mendes, A. A. "Preparation of a biocatalyst via physical adsorption of lipase from Thermomyces lanuginosus on hydrophobic support to catalyze biolubricant synthesis by esterification reaction in a solvent-free system", Enzyme and Microbial Technology, 84, pp. 56-67, 2016.

https://doi.org/10.1016/j.enzmictec.2015.12.007

[62] Manoel, E. A., dos Santos, J. C. S., Freire, D. M. G., Rueda, N., Fernandez-Lafuente, R. "Immobilization of lipases on hydrophobic supports involves the open form of the enzyme", Enzyme and Microbial Technology, 71, pp. 53-57, 2015. https://doi.org/10.1016/j.enzmictec.2015.02.001

[63] Palomo, J. M., Muñoz, G., Fernández-Lorente, G., Mateo, C., Fernández-Lafuente, R., Guisán, J. M. "Interfacial adsorption of lipases on very hydrophobic support (octadecyl-Sepabeads): immobilization, hyperactivation and stabilization of the open form of lipases", Journal of Molecular Catalysis B: Enzymatic, 19-20, pp. 279-286, 2002.

https://doi.org/10.1016/S1381-1177(02)00178-9
[64] Peters, G. H., Olsen, O. H., Svendsen, A., Wade, R. C. "Theoretical Investigation of the Dynamics of the Active Site Lid in Rhizomucor miehei Lipase", Biophysical Journal, 71(1), pp. 119-129, 1996. https://doi.org/10.1016/S0006-3495(96)79207-X

[65] Falus, P., Boros, Z., Kovács, P., Poppe, L., Nagy, J. "LipaseCatalyzed Kinetic Resolution of 1-(2-Hydroxycyclohexyl) Indoles in Batch and Continuous-Flow Systems", Journal of Flow Chemistry, 4(3), pp. 125-134, 2014. https://doi.org/10.1556/JFC-D-14-00011

[66] Hellner, G., Boros, Z., Tomin, A., Poppe, L. "Novel Sol-Gel Lipases by Designed Bioimprinting for Continuous-Flow Kinetic Resolutions", Advanced Synthesis and Catalysis, 353(13), pp. 2481-2491, 2011 https://doi.org/10.1002/adsc.201100329

[67] Ke, C., Li, X., Huang, S., Xu, L., Yan, Y. "Enhancing enzyme activity and enantioselectivity of Burkholderia cepacia lipase via immobilization on modi fi ed multi-walled carbon nanotubes", RSC Advances, 4(101), pp. 57810-57818, 2014. https://doi.org/10.1039/c4ra10517f

[68] Li, X., Xu, L., Wang, G., Zhang, H., Yan, Y. "Conformation studies on Burkholderia cenocepacia lipase via resolution of racemic 1-phenylethanol in non-aqueous medium and its process optimization", Process Biochemistry, 48(12), pp. 1905-1913, 2013. https://doi.org/10.1016/j.procbio.2013.09.001

[69] Peng, L., Feng, A., Liu, S., Huo, M., Fang, T., Wang, K., Wei, Y., Wang, X., Yuan, J. "Electrochemical Stimulated Pickering Emulsion for Recycling of Enzyme in Biocatalysis", ACS Applied Materials and Interfaces, 8(43), pp. 29203-29207, 2016. https://doi.org/10.1021/acsami.6b09920

[70] Wang, J.-Y., Ma, C.-L., Bao, Y.-M., Xu, P.-S. "Lipase entrapment in protamine-induced bio-zirconia particles: Characterization and application to the resolution of $(R, S)$-1-phenylethanol", Enzyme and Microbial Technology, 51(1), pp. 40-46, 2012. https://doi.org/10.1016/j.enzmictec.2012.03.011

[71] Xue, P., Yan, X. H., Wang, Z. "Lipase immobilized on HOOCMCF: A highly enantioselective catalyst for transesterification resolution of $(R, S)$-1-phenylethanol", Chinese Chemical Letters, 18(8), pp. 929-932, 2007. https://doi.org/10.1016/j.cclet.2007.06.005

[72] Li, K., Wang, J., He, Y., Abdulrazaq, M. A., Yan, Y. "Carbon nanotube-lipase hybrid nanoflowers with enhanced enzyme activity and enantioselectivity", Journal of Biotechnology, 281, pp. 87-98, 2018. https://doi.org/10.1016/j.jbiotec.2018.06.344 